\title{
EVALUASI PENERAPAN PROGRAM MANAJEMEN BERBASIS SEKOLAH PADA SEKOLAH DASAR DI PROVINSI DAERAH ISTIMEWA YOGYAKARTA
}

\author{
Ali Mustadi, Unik Ambarwati, Rahayu Condro Murti, dan Supartinah \\ Universitas Negeri Yogyakarta \\ Email : aly_uny@yahoo.com
}

\begin{abstract}
Abstrak
Tujuan dari penelitian ini adalah untuk mengevaluasi sejauh mana keterlaksanaan implementasi program Manajemen Berbasis Sekolah (MBS) Sekolah Dasar (SD) di Daerah Istimewa Yogyakarta (DIY). Subjek penelitian adalah kepala sekolah, guru, dan siswa SD di DIY. Penelitian ini adalah penelitian evaluasi (Evaluative Research). Pengumpulan data menggunakan teknik angket, observasi, dokumentasi. Pendekatan evaluasi yang digunakan dalam penelitian ini yaitu evaluasi model Stake (Stake's Countenance Model) yang membandingkan antara proses pembelajaran yang terjadi dengan proses pembelajaran yang seharusnya. Hasil penelitian ini menunjukkan bahwa implementasi program Manajemen Berbasis Sekolah (MBS) Sekolah Dasar (SD) di Daerah Istimewa Yogyakarta (DIY) berjalan dengan kategori cukup baik. Hal ini didasarkan pada penggunaan desain evaluasi model Stake's Countenance Model yang menekankan adanya pelaksanaan dua hal pokok yakni deskripsi (description) dan pertimbangan keputusan (judgements). Dalam proses implementasi, program MBS mencakup 3 pilar utama yaitu: 1) input (antecedent), 2) proses (transaction), 3) hasil (outcomes).
\end{abstract}

Kata kunci: Program Manajemen Berbasis Sekolah(MBS), Sekolah Dasar (SD)

\section{EVALUATING THE IMPLEMENTATION OF SCHOOL BASED MANAJEMEN PROGRAM IN ELEMENTARY SCHOOLS OF YOGYAKARTA PROVINCE}

\begin{abstract}
The aim of this study is to evaluate the implementation of School Based Manajemen Program in Elementary Schools of Yogyakarta Province. The subjects of the study were headmasters, teachers, students of elementary schools in Yogyakarta province. This study used evaluative method. The data were collected through questionnaire, observation, and documentation. The evaluative approach used in this study was Stake's Countenance Model which compare between the processes occurred in the field and the standard as the criterion of the ideal teaching and learning. The result shows that the implementation of School Based Managemnet program is in 'good' category. This category is based on the analysis which uses evaluative design model of Stake's Countenance Model. The model emphasizes on the 2 aspects: description and judgements. In the process of implementation, school based management covers 3 main components: 1) input (antecedent), 2) process (transaction), 3) output (outcomes).
\end{abstract}

Keywords: School Based Management, Elementary Schools

\section{PENDAHULUAN}

Perkembangan ilmu pengetahuan dan teknologi telah membawa perubahan di hampir semua aspek kehidupan manusia dimana berbagai permasalahan hanya dapat dipecahkan kecuali dengan upaya 
penguasaan dan peningkatan ilmu pengetahuan dan teknologi. Selain manfaat bagi kehidupan manusia di satu sisi perubahan tersebut juga telah membawa manusia ke dalam era persaingan global yang semakin ketat. Agar mampu berperan dalam persaingan global, maka sebagai bangsa kita perlu terus mengembangkan dan meningkatkan kualitas sumber daya manusianya. Oleh karena itu, peningkatan kualitas sumber daya manusia merupakan kenyataan yang harus dilakukan secara terencana, terarah, intensif, efektif dan efisien dalam proses pembangunan, kalau tidak ingin bangsa ini kalah bersaing dalam menjalani era globalisasi tersebut. Strategi input-output yang diperkenalkan oleh teori education production function (Hanushek, 1979) tidak berfungsi sepenuhnya di lembaga pendidikan (sekolah), melainkan hanya terjadi dalam institusi ekonomi dan industri.

Pengelolaan pendidikan selama ini lebih bersifat macro-oriented, diatur oleh jajaran birokrasi di tingkat pusat. Akibatnya, banyak faktor yang diproyeksikan di tingkat makro (pusat) tidak terjadi atau tidak berjalan sebagaimana mestinya di tingkat mikro (sekolah). Atau dengan singkat dapat dikatakan bahwa kompleksitasnya cakupan permasalahan pendidikan, seringkali tidak dapat terpikirkan secara utuh dan akurat oleh birokrasi pusat.

Pendekatan MBS merupakan salah satu sistem yang dikembangkan dalam rangka pemberian kewenangan luas kepada sekolah. Pendekatan ini berpijak pada anggapan dasar bahwa dengan memberikan kewenangan dan kemandirian kepala sekolah akan menciptakan efektivitas dan efisiensi dalam pengelolaan sekolah. Penerapan MBS akan meningkatkan partisipasi warga sekolah (guru, siswa, staf, dan masyarakat) dalam proses persekolahan sehingga pada gilirannya meningkatkan akuntabilitas sekolah kepada warganya.

Konsep MBS telah menarik ahli pendidikan di Indonesia pada akhir 1990-an, dan itu secara resmi diadopsi sebagai mo- del manajemen sekolah di Indonesia dengan disahkannya UU Nomor 20 Tahun 2003 tentang Sistem Pendidikan Nasional. Konsep MBS dipilih didasarkan pada paradigma desentralisasi pendidikan yang diterapkan untuk memecahkan ketidakefektifan dari paradigma pendidikan sentralistik yang sebelumnya diterapkan di Indonesia.

Pelaksanaan Undang-undang yang telah disosialisasikan pada tahun 2003 tentang penyelenggaraan MBS disekolahsekolah ternyata belum berjalan sebagaimana yang diharapkan. Pada tahun 2011 Program Pendidikan Guru Sekolah Dasar telah mengadakan observasi pelaksanaan MBS di DIY dengan mengambil sampel di 4 kabupaten dan kota Yogyakarta. Sekolah yang telah melakukan program MBS adalah SDN 4 Wates, SDN Percobaan 3 Sleman, SDN Bakulan Bantul, SD Muhammadiyah Sapen, dan SDN Piyaman Gunung kidul. Hal-hal yang diobservasi adalah meliputi 3 pilar MBS yaitu Manajemen sekolah, Pelaksanaan pembelajaran PAKEM, dan peran serta orang tua. Hasil dari observasi tersebut semua sekolah menunjukkan rerata 3,3 atau pada kategori baik, walaupun masih ada catatan berupa transparasi dan pengelolaaan dana yang belum optimal, pembelajaran dengan menggunakan pendekatan PAKEM belum semua mata pelajaran dilaksanakan, dan peran serta orang tua masih sebatas tentang pembiayaan sekolah belum menyentuh wilayah peningkatan kualitas sekolah dan proses pembelajaran yang sesuai dengan karakteristik siswa.

Pada tahun 2012 dari hasil observasi tersebut diatas ditindaklanjuti oleh Program Pendidikan Guru Sekolah Dasar dengan melakukan kerjasama dengan 34 Sekolah Dasar di DIY untuk melakukan program pendampingan pelaksanaan MBS dengan memberikan bekal pelatihan bagaimana mekanisme pelaksanaan MBS di sekolah. Kegiatan tersebut mendapat respon positif dari kepala sekolah dan 
guru-guru karena memberikan recharge kembali tentang pelaksanaan MBS yang selama ini belum mereka lakukan sepenuhnya. Kendala yang mereka keluhkan adalah sebagian besar karena minimnya kualitas SDM dan sarana prasarana. Kegiatan ini masih sebatas pemberian wawasan saja belum menyentuh pada bagaimana kontrol pelaksanaannya. Permasalahan tersebut melatarbelakangi adanya penelitian ini, untuk mengevaluasi bagaimana pelaksanaan MBS.

Dalam proses pendidikan ada tiga lingkungan penting yang sangat berpengaruh yaitu keluarga, sekolah dan masyarakat yang mempunyai sasaran yang sama yaitu anak. Pembentukan dewan pendidikan dan komite sekolah tidak terlepas dari upaya mensinergikan dukungan dan peran serta masyarakat baik yang terdiri dari perorangan, kelompok, tokoh masyarakat, dunia usaha, organisasi profesi dan organisasi kemasyarakatan lainnya serta orang tua peserta didik untuk bersama-sama sekolah mengusahakan tercapainya peningkatan mutu, pemerataan dan efisiensi pengelolaan pendidikan secara demokratis dan $a c$ countable dalam rangka tujuan pendidikan nasional.

\section{METODE}

Jenis penelitian ini yaitu penelitian evaluasi (evaluative research) yang bertujuan untuk memperoleh informasi yang akurat dalam mendeskripsikan implementasi program Manajemen Berbasis Sekolah (MBS) yang diselenggarakan oleh Sekolah Dasar (SD) di Daerah Istimewa Yogyakarta (DIY).

Pendekatan evaluasi yang digunakan dalam penelitian ini yaitu evaluasi model Stake (Stake's Countenance Model) yang membandingkan antara proses pembelajaran yang terjadi di lapangan dengan proses pembelajaran yang seharusnya sebagai kriteria untuk menentukan keberhasilan. Desain evaluasi model Stake's Countenance Model menekankan adanya pelaksanaan dua hal pokok yakni deskripsi (description) dan pertimbangan keputusan (judgements). Dua hal pokok ini dibedakan dalam tiga tahap evaluasi program yaitu: 1) input dan perencanaan (antecedent), 2) proses (transaction), 3) hasil (outcomes). Model evaluasi Stake merupakan metode yang sistimatis untuk mengevaluasi keterlaksanaan proses implementasi program MBS secara menyeluruh yang meliputi rencana, pelaksanaan, dan pelaksanan penialian hasil.

Model evaluasi Stake dipilih dengan pertimbangan bahwa penelitian evaluasi yang hendak dilaksanakan dan difokuskan pada evaluasi pelaksanaan implementasi program MBS di propinsi DIY. Desain evaluasi penelitian yang menggunakan evaluasi model Stake, memiliki beberapa tahapan yaitu:

a. Fase Input dan Perencanaan (Antecedent Phase)

Antecedent Phase atau face pendahuluan mendeskripsikan pemahaman guru terhadap rancangan program implementasi program MBS di propinsi DIY, yang terdiri dari: konsep MBS, fungsi dan tujuan, dan manfaat.

b. Fase Pelaksanaan (Transaction Phase) Transaction Phase atau tahap pelaksanaan mendeskripsikan pelaksanaan/implementasi program MBS di propinsi DIY. implementasi program MBS di propinsi DIY meliputi: pelaksanaan administrasi dan organisasi atau tata pamong, pelaksanaan manajemen atau tata kelola, dan pelaksanaan proses implementasi program MBS.

c. Tahap Hasil Program (Output Phase) Output Phase atau tahap hasil program mendeskripsikan pelaksanaan evaluasi implementasi program MBS di propinsi DIY yang diperoleh dari data angket, observasi, dan dokumentasi.

Selanjutnya peneliti membuat suatu pertimbangan keputusan (judgement) terkait dengan pemahaman civitas sekolah terhadap implementasi program MBS di propinsi DIY. Keputusan peneliti ber- 
dasarkan pada dua hal yaitu: (1) standar ideal (absolute standard) yaitu menjelaskan pada proses yang telah terealisasi dan (2) standar relatif (relative standard) yaitu mendasarkan pada suatu standar atau kriteria yang sesuai dengan program MBS. Peneliti akan menghubungkan kaitannya dengan kesesuaian (congruence) antara yang diharapkan (intended) oleh program MBS dengan yang diamati (observed). Penelitian ini dilaksanakan di Sekolah Dasar di wilayah provinsi Daerah Istimewa Yogyakarta, yang meliputi 4 Kabupaten dan 1 Kota. Waktu penelitian dilaksanakan mulai bulan Januari 2013 sampai dengan bulan Oktober 2013. Adapun jadwal kegiatan penelitian terdiri dari persiapan penelitian, pelaksanaan penelitian, penyusunan data, analisis data, dan penyusunan laporan.

\section{HASIL DAN PEMBAHASAN Implementasi Manajemen Sekolah}

Dalam kerangka membangun manajemen sekolah yang akuntabel maka sekolah menyusun visi atas dasar pancasila, UUD 45, dan UU no 20 tahun 2003 tentang Sisdiknas untuk mencapai sekolah yang unggul dalam IPTEK, berwawasan lingkungan, berprestasi, terampil, dan berbudaya berdasarkan iman dan taqwa. Dalam menyusun visi tersebut melalui langkah-langkah: a) merumuskan draft awal bersama warga sekolah, membahas bersama komite sekolah, mensosialisasikan rumusan visi dan misi sekolah kepada civitas sekolah yaitu orangtua siswa, komite sekolah, dan stake holder. Agar semua pihak bisa memahami dan melaksanakan visi tersebut maka secara tertulis visi dipajangkan di tempat yang strategis sehingga mudah dibaca.

Penyusunan visi tersebut kemudian dijabarkan lagi ke Evaluasi Diri Sekolah untuk penyusunan Rencana Kerja Sekolah. Rencana kerja yang disusun dengan melibatkan perwakilan orang tua siswa, pemangku kepentingan, dinas pendidikan, serta tokoh masyarakat sekitar agar mendapat masukan yang produktif. Rencana kerja disusun secara sistematis dan jika ada perubahan maka didasarkan pada analisis kebutuhan sekolah, rencana strategi pengembangan sekolah, dan jika ada perubahan peraturan dari pemerintah.

Muatan dalam Rencana Kerja Anggaran Sekolah yaitu: penanaman rasa hormat pada orang tua, kesadaran bermasyarakat, disipilin dan tertib dalam tugas pekerjaan, taat beribadah sesuai agama yang dianut siswa, budi pekerti dan karakter bangsa yang memuat 18 nilai karakter. Implementasi nilai-nilai tersebut dapat diinyegrasikan pada proses pembelajaran dan kultur sekolah.

Penggunaan dana RKAS 90\% untuk kegiatan-kegiatan sekolah baik yang terprogram maupun insidental. Sisa anggaran $10 \%$ untuk pemeliharaan alat dan gedung sekolah. untuk ketercapaian program sekitar $90 \%$ jika ada perubahan RKS sehingga bisa menjadi $100 \%$. Agar bisa terkontrol, ada pembukuan dan alikasi asset setiap ada perubahan termasuk data ketenagaan dan data siswa didalamnya.

Upaya melaksanakan program sekolah dalam kerangka membangun kultur sekolah yang baik salah satu upaya yang dilakukan adalah: menyediakan dengan jumlah yang cukup toilet putra dan putri dengan penyediaan air bersih serta kondisi bangunan yang terjaga baik. Hal lain adalah membiasakan mereka membuang sampah pada tempatnya, piket yang terjadwal semua itu dilakukan untuk membiasakan menjaga lingkungan yang bersih kepada civitas sekolah.

\section{Pembelajaran Aktif Kreatif Efektif Me- nyenangkan (PAKEM) dalam MBS}

a) Pelaksanaan PAKEM

PAKEM adalah singkatan dari Pembelajaran Aktif, Kreatif, Efektif, dan Menyenangkan. Aktif dimaksudkan bahwa dalam proses pembelajaran guru harus menciptakan suasana sedemikian rupa sehingga siswa aktif bertanya, memper- 
tanyakan, dan mengemukakan gagasan. Peran aktif dari siswa sangat penting dalam rangka pembentukan generasi yang kreatif, yang mampu menghasilkan sesuatu untuk kepentingan dirinya dan orang lain. Kreatif juga dimaksudkan agar guru menciptakan kegiatan belajar yang beragam sehingga memenuhi berbagai tingkat kemampuan siswa. Menyenangkan adalah suasana belajar-mengajar yang menyenangkan sehingga siswa memusatkan perhatiannya secara penuh pada belajar sehingga waktu curah perhatiannya ("time on task") tinggi. Menurut hasil penelitian, tingginya waktu curah perhatian terbukti meningkatkan hasil belajar. Keadaan aktif dan menyenangkan tidaklah cukup jika proses pembelajaran tidak efektif, yaitu tidak menghasilkan apa yang harus dikuasai siswa setelah proses pembelajaran berlangsung, sebab pembelajaran memiliki sejumlah tujuan pembelajaran yang harus dicapai.

Gambaran PAKEM diperlihatkan dengan berbagai kegiatan yang terjadi dimulai dari perencanaan, proses pembelajaran, sampai pada penilaiannya. Pada Tabel 1 kegiatan pembelajaran dan kemampuan guru yang bersesuaian dalam PAKEM berdasarkan data hasil penelitian dari 32 angket yang diisi oleh 32 orang guru.

Berdasarkan Tabel 1 tampak bahwa ketujuh komponen kegiatan pembelajaran dan kemampuan guru yang bersesuaian dalam PAKEM memperoleh rata-rata skor di atas 2 (interval skor, 0-3). Hal ini berarti semua komponen sudah termasuk dalam kategori lebih dari predikat "baik". Skor rata-rata tertinggi pada komponen "guru menyesuaikan bahan dan kegiatan belajar dengan kemampuan siswa" yaitu sebesar 2.679, sedangkan skor rata-rata terendah pada komponen "Guru memberi kesempatan kepada siswa untuk mengembangkan keterampilan" yaitu sebesar 2,277. Menurut penjelasan beberapa guru, memang mereka berusaha untuk menjadikan siswa lebih terampil dengan kegiatan- kegiatan seperti; melakukan percobaan, pengamatan, atau wawancara, mengumpulkan data/jawaban dan mengolahnya sendiri, menarik kesimpulan, memecahkan masalah, mencari rumus sendiri, dan menulis laporan/hasil karya lain dengan kata-kata sendiri, namun karena bahan/ materi yang harus diselesaikan banyak, maka hanya melakukannya sesekali saja.

\section{b) Penilaian Portofolio dalam PAKEM}

Pada penelitian ini rata-rata skor untuk komponen menilai KBM dan kemajuan belajar siswa secara terus menerus adalah 2,595 . Hal ini berarti penilaian portofolio sudah dilaksanakan, guru sudah membuat penilaian mereka benar-benar otentik (authentic assessment) untuk peserta didiknya. Obyek penilaian (evidence) portofolio dapat berupa; 1) hasil kerja peserta didik (artifacts), yaitu hasil kerja peserta didik yang dihasilkan di dalam kelas, 2) reproduksi (reproduction) yaitu hasil kerja peserta didik yang dikerjakan di luar kelas, 3) pengesahan (attestations) yaitu pernyataan dan hasil pengamatan yang dilakukan oleh guru atau pihak lain tentang peserta didik, dan 4) produksi (productions) yaitu hasil kerja peserta didik yang dipersiapkan khusus untuk portofolio. Penilaian portofolio diwujudkan oleh guru dengan menyiapkan papan pajangan bagi hasil karya seluruh siswa.

Masing-masing siswa memiliki map plastik yang ditempelkan pada dinding kelas. Map ini digunakan untuk menyimpan hasil karya siswa selama satu semester, dengan demikian guru mudah melakukan penilaian portofolio dan mengetahui perkembangan pengetahuan siswa dan kemampuan dalam mata pelajaran tertentu, serta pertumbuhan kemampuannya. Portofolio dapat memberikan bahan tindak lanjut dari satu pekerjaan yang telah dilakukan siswa sehingga guru dan peserta didik berkesempatan untuk mengembangkan kemampuannya. Selain itu, penilaian dengan menggunakan porto- 
folio ini juga untuk memberikan informasi kepada orang tua tentang perkembangan puta-putri mereka secara lengkap dengan dukungan data dan dokumen yang akurat.
Peran Orang Tua dalam Manajemen Berbasis Sekolah

\section{a) Keterlibatan Aktif Orang Tua dalam} MBS

Orang tua adalah salah satu mitra sekolah yang dapat berperan serta dalam meningkatkan mutu pendidikan sekolah.

Tabel 1. Kegiatan pembelajaran dan kemampuan guru yang bersesuaian dalam PAKEM

\begin{tabular}{|c|c|c|c|}
\hline & Kemampuan Guru & Kegiatan Pembelajaran & Rata-rata skor \\
\hline & $\begin{array}{l}\text { Guru merancang dan } \\
\text { mengelola KBM yang } \\
\text { mendorong siswa untuk } \\
\text { berperan aktif dalam } \\
\text { pembelajaran } \\
\text { (no. } 1-5,16)\end{array}$ & $\begin{array}{l}\text { Guru melaksanakan pembelajaran dalam kegiatan } \\
\text { yang beragam, misalnya: } \\
\text { - Percobaan } \\
\text { - Diskusi kelompok } \\
\text { - Memecahkan masalah } \\
\text { - Mencari informasi } \\
\text { - Menulis laporan/cerita/puisi } \\
\text { Berkunjung keluar kelas }\end{array}$ & 2.521428 \\
\hline 2. & $\begin{array}{l}\text { Guru menggunakan alat } \\
\text { bantu dan sumber belajar } \\
\text { yang beragam. } \\
\text { (no. } 6-9,17-19 \text { ) }\end{array}$ & $\begin{array}{l}\text { Sesuai mata pelajaran, guru menggunakan, misal: } \\
\text { - Alat yang tersedia atau yang dibuat sendiri } \\
\text { - Gambar } \\
\text { - Studi kasus } \\
\text { - Nara sumber Lingkungan }\end{array}$ & 2.321429 \\
\hline 3. & $\begin{array}{l}\text { Guru memberi kesempatan } \\
\text { kepada siswa untuk } \\
\text { mengembangkan } \\
\text { keterampilan. } \\
\text { (no. } 10-12,20)\end{array}$ & $\begin{array}{l}\text { Siswa: } \\
\text { - Melakukan percobaan, pengamatan, atau } \\
\text { wawancara } \\
\text { - Mengumpulkan data/jawaban dan mengolahnya } \\
\text { sendiri } \\
\text { - Menarik kesimpulan } \\
\text { - Memecahkan masalah, mencari rumus sendiri } \\
\text { Menulis laporan/hasil karya lain dengan kata-kata } \\
\text { sendiri }\end{array}$ & 2.2767857 \\
\hline 4. & $\begin{array}{l}\text { Guru memberi kesempatan } \\
\text { kepada siswa untuk } \\
\text { mengungkapkan } \\
\text { gagasannya sendiri secara } \\
\text { lisan atau tulisan. } \\
\text { (no. } 13-15,21,28 \text { ) }\end{array}$ & $\begin{array}{l}\text { Melalui: } \\
\text { - Diskusi } \\
\text { - Lebih banyak pertanyaan terbuka. Hasil karya } \\
\text { yang merupakan pemikiran anak sendiri }\end{array}$ & 2.5 \\
\hline 5. & $\begin{array}{l}\text { Guru menyesuaikan bahan } \\
\text { dan kegiatan belajar } \\
\text { dengan kemampuan siswa. } \\
\text { (no. 22) }\end{array}$ & $\begin{array}{l}\text { Siswa dikelompokkan sesuai dengan kemampuan } \\
\text { (untuk kegiatan tertentu) } \\
\text { Bahan pelajaran disesuaikan dengan kemampuan } \\
\text { kelompok tersebut. Tugas perbaikan atau pengayaan } \\
\text { diberikan }\end{array}$ & 2.678571429 \\
\hline 6. & $\begin{array}{l}\text { Guru mengaitkan KBM } \\
\text { dengan pengalaman siswa } \\
\text { sehari-hari. } \\
\text { (no. } 25 \text { ) }\end{array}$ & $\begin{array}{l}\text { Siswa menceritakan atau memanfaatkan } \\
\text { pengalamannya sendiri. } \\
\text { Siswa menerapkan hal yang dipelajari dalam } \\
\text { kegiatan sehari-hari }\end{array}$ & 2.535714 \\
\hline 7. & $\begin{array}{l}\text { Menilai KBM dan } \\
\text { kemajuan belajar siswa } \\
\text { secara terus menerus. } \\
\text { (no. } 23,24 \& 26 \text { ) }\end{array}$ & $\begin{array}{l}\text { Guru memantau kerja siswa } \\
\text { Guru memberikan umpan balik }\end{array}$ & 2.595238 \\
\hline
\end{tabular}


Melalui orang tua kegiatan belajar anak di rumah dapat dipantau. Bahkan orang tua dapat menjadi bagian dari paguyuban para orang tua siswa yang dapat memberi masukan dan dukungan dalam merencanakan pengembangan sekolah.

Keterlibatan orang tua selain sebagai bentuk kepedulian terhadap kemajuan pendidikan anak, juga sebagai bentuk partisipasi mereka dalam sistem manajemen sekolah. Pada konsep MBS, orang tua dapat terlibat secara aktif mulai dari perencanaan, pelaksanaan, dan pemantauan kemajuan dan perkembangan sekolah dalam mewujudkan akuntabilitas sekolah. Peran serta itu dapat terjadi dalam pembelajaran, perencanaan pengembangan sekolah, dan pengelolaan kelas.

1) Peran Serta Orang Tua dalam Pembelajaran

Orang tua tidak saja membantu belajar anak di rumah, bisa juga dilakukan di sekolah. Bahkan kalau perlu orang tua yang memiliki pengetahuan dan keahlian khusus, misalnya ahli dalam musik atau seni rupa, dengan koordinasi yang baik dengan pihak sekolah, para orang tua ini bisa saja membantu mengadakan proses pembelajaran musik dan seni rupa pada ekstrakurikuler di sekolah.

Para pakar sepakat bahwa ada tujuh jenis peran serta orang tua dalam pembelajaran (Depdiknas, 2001:2-7).

1. Hanya sekedar pengguna jasa pelayanan pendidikan yang tersedia. Misalnya, orang tua hanya memasukkan anak ke sekolah dan menyerahkan sepenuhnya kepada pihak sekolah.

2. Memberikan kontribusi dana, bahan, dan tenaga, misalnya dalam pembangunan gedung sekolah.

3. Menerima secara pasif apa pun yang diputuskan oleh pihak yang terkait dengan sekolah, misalnya komite sekolah.

4. Menerima konsultasi mengenai hal-hal yang terkait dengan kepentingan sekolah. Misalnya, kepala sekolah berkonsultasi dengan komite sekolah dan orang tua murid mengenai masalah pendidikan, masalah pembelajaran matematika. Dalam konsep MBS hal yang keempat ini harus selalu terjadi.

5. Memberikan pelayanan tertentu. Misalnya, sekolah bekerja sama dengan mitra tertentu seperti Komite Sekolah dan orang tua murid mewakili sekolah bekerjasama dengan Puskesmas untuk memberikan penyuluhan tentang perlunya sarapan pagi sebelum sekolah, atau makanan yang bergizi bagi anakanak.

6. Melaksanakan kegiatan yang telah didelegasikan atau dilimpahkan sekolah. Sekolah, misalnya, meminta komite sekolah dan orang tua murid tertentu untuk memberikan penyuluhan kepada masyarakat umum tentang pentingnya pendidikan atau hal-hal penting lainnya untuk kemajuan bersama.

7. Mengambil peran dalam pengambilan keutusan pada berbagai jenjang. Misalnya orang tua siswa ikut serta membicarakan dan mengambil keputusan tentang rencana kegiatan pembelajaran di sekolah, baik dalam pendanaan, pengembangan dan pengadaan alat bantu pembelajarannya.

\section{2) Peran Serta Orang Tua dalam Perenca- naan Pengembangan Sekolah}

Dalam perencanaan pengembangan sekolah, orang tua merupakan salah satu peran penting. Orang tua dapat berperan serta dalam menyediakan dana, prasarana dan sarana sekolah sebagai upaya realisasi program-program sekolah yang telah disusun bersama. Orang tua yang memiliki pendidikan, pengetahuan, dan keterampilan khusus dapat berperan serta dalam membantu sekolah seperti pada bidang proses pembelajaran, pengelolaan persekolahan, dan pengelolaan keuangan sekolah. Orang tua siswa dapat berperan serta dalam perencanaan pengembangan sekolah. 
Banyak cara yang dapat ditempuh orang tua siswa dalam perencanaan pengembangan sekolah. Orang tua dapat datang ke sekolah tanpa/dengan undangan sekolah yang mengundang. Sekelompok orang tua mengadakan pertemuan di luar sekolah untuk bersama-sama membahas dan memberikan masukan untuk peningkatan mutu sekolah, hasilnya kemudian diserahkan kepada sekolah.

\section{3) Peran Serta Orang Tua dalam Pengelolaan Kelas}

Keterlibatan orang tua siswa dalam pengelolaan kelas memiliki arti yang sangat luas bukan berarti orang tua turut masuk ke kelas dan campur tangan mengurusi tempat duduk siswa, memindah siswa yang suka mengganggu temannya di kelas, dan sebagainya. Tetapi, pengaturan kelas dapat dilakukan berdasarkan masukan dengan dan/atau kompromi dengan para orang tua.

4) Upaya-Upaya yang dilakukan Sekolah untuk Meningkatkan Peran Serta Orang Tua dalam Mendukung Proses Keberhasilan Sekolah dalam Rangka MBS

Sangat penting bagi sekolah untuk menjalankan peranan kepemimpinan yang aktif dalam menggalakkan programprogram sekolah melalui peran serta aktif orang tua dan masyarakat. Ada beberapa hal yang harus dipertimbangkan dalam mengupayakan partisipasi orang tua dan masyarakat terhadap keberhasilan program sekolah, diantaranya:

a) Menjalin Komunikasi yang Efektif dengan

Orang Tua dan Masyarakat

Partisipasi orang tua dan masyarakat akan tumbuhjika orang tua dan masyarakat juga merasakan manfaat dari keikutsertaanya dalam program sekolah. Manfaat dapat diartikan luas, termasuk rasa diperhatikan dan rasa puas karena dapat menyumbangkan kemampuannya bagi kepentingan sekolah. Jadi prinsip menumbuhkan hubungan dengan masyarakat adalah saling memberikan kepuasan. Salah satu jalan penting untuk membina hubungan dengan masyarakat adalah menetapkan komunikasi yang efektif. Ada beberapa pendekatan yang dapat digunakan untuk membangun komunikasi dengan orang tua dan masyarakat, yaitu:

1. Mengidentifikasi orang-orang kunci, yaitu orang-orang yang mampu mempengaruhi teman lain,

2. Melibatkan orang-orang kunci tersebut dalam kegiatan sekolah, khususnya yang sesuai dengan minatnya, dan

3. Memilih saat yang tepat.

b) Melibatkan Masyarakat dan Orang Tua dalam Program Sekolah

Pepatah "Tak senang jika tak kenal" juga berlaku dalam hal ini. Oleh karena itu sekolah harus mengenalkan program dan kegiatannya kepada masyarakat. Dalam program tersebut harus tampak manfaat yang diperoleh masyarakat jika membantu program sekolah. Untuk maksud diatas, sekolah dapat melakukan:

1. Melaksanakan program-program kemasyarakatan

2. Mengadakan open house yang memberi kesempatan masyarakat luas untuk mengetahui program dan kegiatan sekolah.

3. Mengadakan buletin sekolah atau majalah atau lembar informasi yang secara berkala memuat kegiatan dan program sekolah, untuk diinformasikan kepada masyarakat.

4. Mengundang tokoh untuk menjadi pembicara atau pembina suatu program sekolah

5. Membuat program kerja sama sekolah dengan masyarakat.

c) Memberdayakan Dewan Sekolah

Keberadaan Dewan Sekolah akan menjadi penentu dalam pelaksanaan otonomi pendidikan di sekolah. Melalui Dewan Sekolah orang tua dan masyarakat ikut merencanakan, melaksanakan, dan 
mengawasi pengelolaan pendidikan di sekolah. Untuk meningkatkan komitmen peran serta masyarakat dalam menjunjang pendidikan, termasuk dari dunia usaha, perlu dilakukan antara lain dengan upaya sebagai berikut:

1. Melibatkan masyarakat dalam pengambilan keputusan tentang pendidikan terutama ditingkat sekolah,

2. Selanjutnya program imlab swadana, dan

3. Mengembangkan sistem sponsorship bagi kegiatan pendidikan.

Melalui upaya-upaya yang dilakukan pihak sekolah dalam meningkatkan partisipasi masyarakat dan orang tua dalam mendukung program-program sekolah dapat teroptimalkan.

\section{PENUTUP}

Kesimpulan

Implementasi Manajemen Berbasis Sekolah (MBS) Sekolah Dasar di Daerah Istimewa Yogyakarta, dapat disimpulkan bahwa semua komponen dari fase input dan perencanaan, fase pelaksanaan, tahap hasil program sudah termasuk dalam kategori lebih dari predikat "baik". Skor rata-rata tertinggi pada komponen "guru menyesuaikan bahan dan kegiatan belajar dengan kemampuan siswa" yaitu sebesar 2.679, sedangkan skor rata-rata terendah pada komponen "Guru memberi kesempatan kepada siswa untuk mengembangkan keterampilan" yaitu sebesar 2,277.

\section{Saran}

Sekolah diharapkan mampu menggali dan mengelola semua jenis partisipasi orang tua dan masyarakat dalam mendukung keberhasilan program-program sekolah sesuai dengan kebutuhan masing-masing, baik berupa patisipasi buah pikiran, tenaga, harta benda, keterampilan maupun partisipasi sosial. Upaya meningkatkan partisipasi orang tua dan masyarakat, maka diperlukan hubungan dan kerjasama yang harmonis antara sekolah dan masyarakat serta mempunyai kemampuan majerial dan tenaga yang profesional untuk menciptakann programprogram sekolah yang berkualitas.

\section{DAFTAR PUSTAKA}

Depdiknas. (2001). Konsep dan Pelaksanaan dalam Manajemen Peningkatan Mutu Berbasis Sekolah. Jakarta: Dikmenum.

Hanushek, Eric A. (1979). Conceptual and Empirical Issues in the Estimation of Education Production Function. Dimuat dalam The Journal of Human Resources, Volume 14 Issue 3 (Summer, 1979), 351-388p. Diakses dari http://gse.buffalo.edu/fas/yerrick/ ubscience/UB Science Education Goes to School/21C Literature files/ hanushek,\%201979.pdf, pada 3 Februari 2013. 